\title{
Comparative analysis of long term survival of pediatric and adult living donor renal transplantation: single center IOyears experience
}

\begin{abstract}
Our objective was to highlight the results of comparative analysis of pediatric and adults living donor renal transplantation in a single center experience extended for more than 30 years. The study comprised of 1902 adults and 338 children aging 18 years or younger. Male sex was dominant among recipients of both groups in contrary to female sex that constituted for $75.9 \%$ for adults and $63.6 \%$ for pediatrics. No statistical difference was encountered for patient survival at 5 and $10 y e a r s$ for both groups. A significant difference was observed between pediatrics and adults 10years graft survival. Moreover comparable patients are living enjoying good graft function for both groups at last follow up. The significant outcome predictors for graft survival for pediatrics were primary immunosuppression, acute rejection and post transplant hypertension while the corresponding factors for adults included donor age $>40$ years, primary immunosuppression, acute rejection, and post transplant hypertension. Multivariate analysis revealed that acute rejection sustained its impact for pediatrics while donor age $>40$ years, primary immunosuppression, acute rejection and post transplant hypertension still had a significant effect on outcome for the adults.
\end{abstract}

Keywords: living donor transplantation, pediatrics transplantation, adult transplantation, long term graft survival
Volume 2 Issue 3 - 2015

\author{
Ahmed Akl,' Ahmed H Neamatalla,' Ayman \\ M Nagib,' Mohamed Adel Bakr,' Ashraf \\ Foda,' Ehab WWafa,' Ahmed A Shokeir, ${ }^{2}$ \\ Mohamed A Ghoneim² \\ 'Department of Nephrology, Urology and Nephrology Center, \\ Egypt \\ ${ }^{2}$ Department of Urology, Urology and Nephrology Center, \\ Egypt
}

Correspondence: Ahmed I Akl, Urology and Nephrology center, Mansoura, Egypt, Tel 20502262222, Fax 2050223717, Email aiak1200।@yahoo.com

Received: March 01, 2015 | Published: April 09, 2015
Abbreviations: ATN, acute tubular necrosis; Aza, azathioprine; CsA, cyclosporine a; MMF, mycophenolate mofeti

\section{Introduction}

Renal transplantation is the treatment option of choice for children suffering from end stage renal diseases. ${ }^{1}$ Children have a unique situation that differs from the adults. Compliance on dialysis, school attendance, growth and puberty beside surgical, immunologic and psychological aspects are contributing factors for that difference between children and adults. ${ }^{2}$

Numerous reports all over the world highlighted aspects and results of adult transplantation. However pediatric transplantation outcome was published at a lesser extent. Scare comparative studies between the two population groups are reviewed in the literature. Herein, we highlighted the results of comparative analysis of pediatric and adult living donor kidney transplantation in a single center experience extended from more than 30years.

\section{Materials and methods}

Between March 1976 and June 2011, 2240 consecutive living donor renal transplantation were carried out at Mansoura urology and nephrology center, Egypt, 1902 were above 18years (adult group $84.9 \%$ ) while 338 were, aged 18years or below (pediatric recipients, $15.1 \%$ ). Demographic characteristics, primary immunosuppression plan, original kidney diseases, causes of death either with functioning graft or with failed one, rejection episodes, complications beside condition and clinical grading at last follow up.

For recipients, our exclusion criteria for transplantation included sensitization with a Positive lymphocytotoxic cross match, recent malignancy, addiction, psychiatric disorders, type I diabetes mellitus, active infection and significant extra-renal organ disease (pulmonary, hepatic and cardiac). Contraindications to donation included: age above 60years or below 21years, active infections, diabetes, any minimal renal functional impairment, proteinuria or hematuria. Hypertension and serology test results positive for HIV, HBV or HCV.

The graft function was monitored by periodic estimation of serum creatinine and creatinine clearance. Data were organized to provide analyses of patient and graft survival rates and the predictors for 10 -year graft survival. Evaluation of the possible variables that may affect the graft survival was carried out using univariate analysis and multivariate analysis. Studies factors included age, sex, original kidney disease, relationship of donor and recipient, $\mathrm{ABO}$ blood group equality, pre-transplant blood transfusion, HLA and DR matching, pre-transplant dialysis, cold ischemia time, number of renal arteries, urinary re-continuity, time to diuresis, time of transplantation, occurrence of acute tubular necrosis (ATN), primary and secondary immunosuppression, total dose of steroids in the first 3months, development of acute rejection and post-transplant hypertension. ATN was defined by the need for dialysis during the first week after transplantation. Hemodialysis was the comments form of dialysis before transplantation $(92 \%)$. 
Most patients that received transplants before 1988 were treated with daily oral administration of $7.5-15 \mathrm{mg}$ prednisolone (the mean daily dose at 6 months post-transplantation was $0.3 \mathrm{mg} / \mathrm{kg}$ and was reduced thereafter) and $2.5 \mathrm{mg} / \mathrm{kg}$ azathioprine (Aza) as combined therapy. From 1988 to 1998 a triple-therapy regimen comprising daily prednisolone between $5 \mathrm{mg}$ and $10 \mathrm{mg}$ (the mean daily dose at 6 months post-transplant was $0.25 \mathrm{mg} / \mathrm{kg}$ and was reduced thereafter), azathioprine $2 \mathrm{mg} / \mathrm{kg}$ and cyclosporine A (CsA) was administered. Alternate-day prednisolone was used in 48 patients $(22 \%)$. Cyclosporine whole-blood trough levels were maintained between $100 \mathrm{ng} / \mathrm{ml}$ and $150 \mathrm{ng} / \mathrm{ml}$. Tacrolimus and mycophenolate mofetil (MMF) have been introduced as a primary therapy since 1998, and sirolimus has been used since 2002, in addition to prednisolone. No induction therapy was used. Acute rejection episodes (requiring confirmation of renal pathology by biopsy prior to anti-rejection treatment) were treated with intravenous bolus doses of methylprednisolone (250-500mg/day) for three to five consecutive days. Steroid-resistant patients were treated with plasmapheresis (15 patients) on alternate days for up to 10days and/ or ATG (six patients) or OKT3 (two patients). Plasmapheresis was performed with Gambro AK 10 and AK 100 machines.

A 1.4 volume pheresis was performed with replacement of plasma by $5 \%$ albumin. The duration of pheresis and blood flow rate was determined according to patient height, weight, hematocrit, and tolerance to anticoagulation. TB was diagnosed by one or more of the following methods:

a) Demonstration of acid-fast bacilli in urine and sputum and/or growth in different culture specimens.

b) Demonstration of mycobacterial tuberculous antigens in urine, sputum or blood using polymerase chain reaction.

c) Demonstration of caseating granuloma by histopathologic examination.

d) Radiological findings indicating $\mathrm{TB}$ in a chest X-ray or a CT scan. Standard deviation scores for height were calculated as follows: observed height-expected height for age/standard deviation of mean height for age. Graft failure was defined as the start of any other form of renal replacement therapy, or a creatinine clearance of less than $10 \mathrm{ml} / \mathrm{min}$ per $1.73 \mathrm{~m}^{2}$. Death with functioning graft was considered as graft failure.

\section{Statistical analysis}

Kaplan-Meier curves and log-rank tests were used to describe and compare the graft survival rates in stratified univariate analyses. Tests of significance were carried out using the chi-square method, with a $P$ value of $<0.05$ taken to indicate statistical significance. All $P$ values were two-sided. A multivariate analysis of graft survival was performed using Cox proportional hazards regression models to adjust for potentially confounding variables that could influence outcomes. The SPSS statistics package (SPSS V11.0, SPSS Inc., USA) was used for these analyses. ${ }^{3}$

\section{Results}

Our overall experience of living donor renal transplantation constituted $15.1 \%$ pediatrics and $84.9 \%$ adults. The male sex was dominant among both groups (63.6\% vs $75.9 \%)$, as regard the donor female sex it was $68.3 \%$ in the pediatrics versus $50.2 \%$ in adults. The mean age of recipients was $13.7+3.9$ years and $32.3+9.1$ years for both groups and the corresponding figures for donor age was $37.7+8.2$ years and $35.6+10.5$ years respectively (Table 1A) chronic GN and PN represented $19.5 \%, 11.5 \%$ as original kidney disease for pediatrics and $9 \%, 12.4 \%$ for adults. Majority of donors were related ( $83 \%$ vs $17 \%$ ), with same blood group $(80.3 \%$ vs $19.6 \%)$ and $50 \%$ HLA matching was $(80.6 \%$ vs $74.9 \%)$. Hypertensive recipients were $42.3 \%$ vs $61.1 \%$ while pre-emptive transplantation was carried out in $9.2 \%$ in pediatric group and $3.9 \%$ of adult group. Concerning immunosuppression, induction therapy was utilized in $52.1 \%$ and $50.3 \%$ for both groups. The CsA based immunosuppression protocols adapted for pediatrics $59.2 \%$ and for $60.7 \%$ adults were comparable, similarly the pre transplant blood transfusion (39.1\% vs $43.4 \%)$ (Table 1B).

Table IA Demographic characteristics

\begin{tabular}{|c|c|c|c|}
\hline & Pediatrics No. (\%)(No.=338) & Adults No. $(\%)($ No. $=1902)$ & P-value \\
\hline Recipient Male sex & $215(63.6)$ & 1443 (75.9) & $<0.001$ \\
\hline Donors female sex & $231(68.3)$ & $955(50.2)$ & $<0.001$ \\
\hline $\begin{array}{l}\text { Age of donors } \\
<30 \\
30-50 \\
>50\end{array}$ & $\begin{array}{l}67(19.8) \\
251(74.3) \\
20(5.9)\end{array}$ & $\begin{array}{l}774(40.7) \\
930(48.9) \\
198(10.4)\end{array}$ & $<0.001$ \\
\hline $\begin{array}{l}\text { Original kidney disease } \\
\text {-Ch. GN } \\
\text {-Ch PN } \\
\text {-ESK }\end{array}$ & $\begin{array}{l}66(37.1) \\
39(21.9) \\
71(27.7)\end{array}$ & $\begin{array}{l}|7|(23) \\
235(31.7) \\
547(42.1)\end{array}$ & $<0.001$ \\
\hline $\begin{array}{l}\text { Consanguinity } \\
\text {-Related } \\
\text {-Unrelated }\end{array}$ & $\begin{array}{l}306(90.5) \\
32(9.5)\end{array}$ & $\begin{array}{l}1554(81.7) \\
348(18.3)\end{array}$ & $<0.001$ \\
\hline Same Blood group & $262(77.5)$ & 1537 (80.9) & 0.155 \\
\hline
\end{tabular}


Table continued...

\begin{tabular}{|c|c|c|c|}
\hline & Pediatrics No. (\%)(No.=338) & Adults No. (\%)(No.=|902) & P-value \\
\hline Pre-Tx dialysis & $307(90.8)$ & I827 (96.I) & $<0.001$ \\
\hline Pre-Tx HTN & $143(42.3)$ & $1162(61.1)$ & $<0.001$ \\
\hline Bilharziasis & $29(8.6)$ & $502(26.4)$ & $<0.001$ \\
\hline 50\% HLA Matching & $233(80.6)$ & I29| (74.9) & 0.037 \\
\hline Induction therapy & $176(52.1)$ & $956(50.3)$ & 0.54 \\
\hline $\begin{array}{l}\text { Primary plan IS } \\
\text {-Aza based } \\
\text {-Csa based } \\
\text {-Fk based } \\
\text {-Rapa based } \\
\text {-Steroid free }\end{array}$ & $\begin{array}{l}23(6.8) \\
200(59.2) \\
21(6.2) \\
3(0.9) \\
82(24.3)\end{array}$ & $\begin{array}{l}286(15.2) \\
1154(60.7) \\
112(5.9) \\
136(7.2) \\
170(8.9)\end{array}$ & $<0.001$ \\
\hline $\begin{array}{l}\text { Blood transfusion } \\
\text { - yes }\end{array}$ & $132(39.1)$ & $826(43.4)$ & 0.097 \\
\hline $\begin{array}{l}\text { Primary Ur. Continuity } \\
\text { - U-V } \\
\text { - U-U }\end{array}$ & $\begin{array}{l}326(96.4) \\
10(3)\end{array}$ & $\begin{array}{l}1877(98.6) \\
20(1.1)\end{array}$ & 0.02 \\
\hline Immediate diuresis & $299(88.5)$ & $1769(93)$ & 0.004 \\
\hline
\end{tabular}

Table IB Demographic characteristics

\begin{tabular}{|c|c|c|c|}
\hline & Pediatrics No. $($ No. $=338)$ & Adults No. $($ No. $=1902)$ & P-value \\
\hline Re-Transplantation & $4(1.2)$ & $79(4.2)$ & 0.022 \\
\hline P.O. Mortality ( 10 years) & $43(12.7)$ & $323(17)$ & 0.105 \\
\hline Post transplant hypertension & $17 \mid(50.6)$ & $1163(61.1)$ & $<0.001$ \\
\hline Post transplant DM & $17(5)$ & $413(21.7)$ & $<0.001$ \\
\hline Post transplant malignancy & $7(2.1)$ & $96(5)$ & 0.016 \\
\hline $\begin{array}{l}\text { Secondary IS } \\
\text { Yes }\end{array}$ & $147(43.5)$ & $884(46.5)$ & 0.31 \\
\hline $\begin{array}{l}\text { Secondary IS } \\
\text {-Aza based } \\
\text {-Csa based } \\
\text {-Fk based } \\
\text {-Rapa based }\end{array}$ & $\begin{array}{l}4(1.2) \\
79(23.4) \\
49(14.5) \\
---\end{array}$ & $\begin{array}{l}35(1.8) \\
534(28.1) \\
197(10.4) \\
5(0.3)\end{array}$ & 0.656 \\
\hline Urologic complications & $25(7.4)$ & $132(6.9)$ & 0.417 \\
\hline Bacterial infection & $49(14.5)$ & $389(20.5)$ & 0.006 \\
\hline Viral infection & $30(8.9)$ & $209(\mathrm{II})$ & 0.143 \\
\hline II-ATN & $22(6.5)$ & $97(5.1)$ & 0.287 \\
\hline Rejection (yes) & I $27(4||)$. & $745(4 I .6)$ & 0.87 \\
\hline Rejection frequency $(>2)$ & $108(32)$ & 49I (25.8) & 0.024 \\
\hline $\begin{array}{l}\text { Rejection type } \\
\text {-Acute cellular } \\
\text {-Acute vascular } \\
\text { - Chronic }\end{array}$ & $\begin{array}{l}115(34) \\
10(3) \\
85(25.1)\end{array}$ & $\begin{array}{l}663(34.9) \\
71(3.7) \\
382(20.1)\end{array}$ & 0.035 \\
\hline $\begin{array}{l}\text { Serum creatinine } \\
\text {-First year } \\
-2 \text { nd year } \\
-3 \text { rd year } \\
-4 \text { th year } \\
-5 \text { th year }\end{array}$ & $\begin{array}{l}1.28+0.77 \\
1.46+0.82 \\
1.60+1.09 \\
1.72+1.10 \\
1.77+1.09\end{array}$ & $\begin{array}{l}1.40+0.66 \\
1.52+0.81 \\
1.62+0.92 \\
1.65+1.01 \\
1.69+1.02\end{array}$ & $\begin{array}{l}0.006 \\
0.27 \\
0.834 \\
0.364 \\
0.292\end{array}$ \\
\hline
\end{tabular}


The post-transplant results outlined in Table 1B revealed comparable mortality at 10 years $(12.7 \%$ vs $17 \%)$, post transplant hypertension $(50.6 \%$ vs $61.1 \%)$, secondary immunosuppression (43.5\% vs $46.5 \%)$, urologic complications $(7.4 \%$ vs $6.9 \%)$, acute cellular rejection (34\% vs $34.9 \%$ ), acute vascular rejection ( $3 \%$ vs $3.7 \%)$. While pediatric recipients experienced higher ATN $(6.5 \%$ vs $5.1 \%$ ), chronic rejection $(25.1 \%$ vs $20.1 \%)$. On the other hand, adults had increased post transplant DM $21.75 \%$ vs $5 \%$ in pediatric group, Malignancy ( $2.1 \%$ in pediatrics vs $5 \%$ in adults), re-transplantation
(1.2\% vs $4.2 \%)$ immediate diuresis ( $88.5 \%$ vs $93 \%)$, bacterial infections ( $14.5 \%$ vs $20.5 \%$ ) and viral infection ( $8.9 \%$ vs $11 \%)$. The leading causes of death with functioning grafts in pediatric group are trauma and bleeding, CV and respiratory, while the causes of mortality with failed graft included CV, GIT and liver dysfunction, respiratory. On the other hand the causes of death with functioning grafts in adults are $\mathrm{CV}$, respiratory, GIT, hepatic and malignancy. The prominent causes of death with failed graft in adults CV, GIT, hepatic (Table 2).

Table 2 Causes of death

\begin{tabular}{|c|c|c|}
\hline With functioning graft & Pediatrics No. & Adults No. \\
\hline C.V. & $3(21.4)$ & $46(18.3)$ \\
\hline Resp. & I (7.I) & $28(11.1)$ \\
\hline Blood + Trauma & $3(21.4)$ & $3(1.2)$ \\
\hline Malignancy & $2(14.3)$ & $25(9.9)$ \\
\hline GIT + liver & -- & $31(8.7)$ \\
\hline Infection & -- & $27(10.7)$ \\
\hline Cerebral & -- & $17(6.7)$ \\
\hline Unknown & -- & $\mathrm{I}(0.4)$ \\
\hline With failed graft & Pediatrics No. & Adults No. \\
\hline C.V. & $10(31.3)$ & $40(24.4)$ \\
\hline Resp. & $2(6.3)$ & $22(13.4)$ \\
\hline GIT + liver & $2(6.2)$ & $21(12.8)$ \\
\hline Infection & $2(6.3)$ & $12(7.3)$ \\
\hline Malignancy & -- & $9(5.5)$ \\
\hline Unknown & $16(50)$ & $55(33.5)$ \\
\hline
\end{tabular}

At last follow up more or less patients are living enjoying graft function $(57.1 \%$ vs $53.5 \%)$. Serum creatinine was significantly lower $(1.28+0.77 \mathrm{mg} / \mathrm{dl})$ in pediatric group compared to Adult group $(1.40+0.66 \mathrm{mg} / \mathrm{dl})$ in the first year but later it become comparable (Table 1B). The actuarial patient survival at 5 and 10years were $91.6+1.74$ and $81.63+2.92$ for pediatrics and $89.51+0.76,77.36+1.25$ for adults. The corresponding figures for the graft survival were $83.9+2.28,58.34+3.53$ for pediatrics and $87.24+0.84,66.78+1.38$ for adults respectively, $\mathrm{p}<0.001$ (Figure 1) (Figure 2).

Outcome predictors of graft survival for pediatrics were Donor age $\geq 40$ years, type of primary immuno suppression, acute rejection and post transplant hypertension by univariate analysis for both groups. While those who act independently in multivariate analysis were only acute rejection for pediatrics. While for adults were Donor age $\geq 40$ years, steroid free based primary immunosuppression, acute rejection and post transplant hypertension (Table 3) (Table 4). 


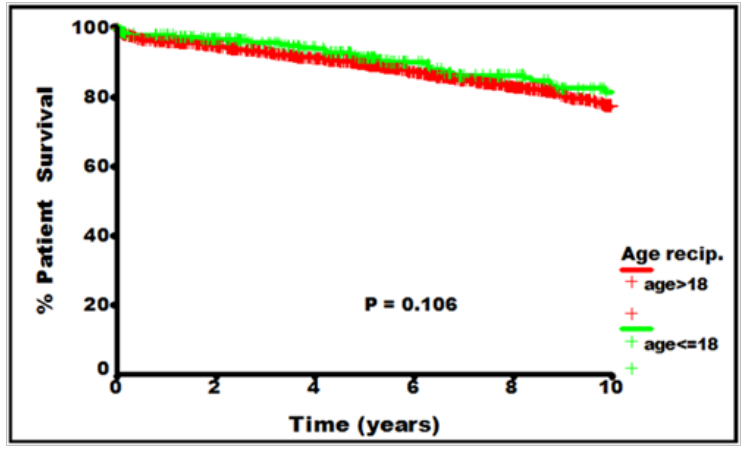

Figure I Patient survival.

The actuarial patient survival at 5 and 10 years were $91.6+1.74$ and $81.63+2.92$ for pediatrics and $89.5 \mathrm{I}+0.76,77.36+\mathrm{I} .25$ for adults $\mathrm{p}=0.106$.

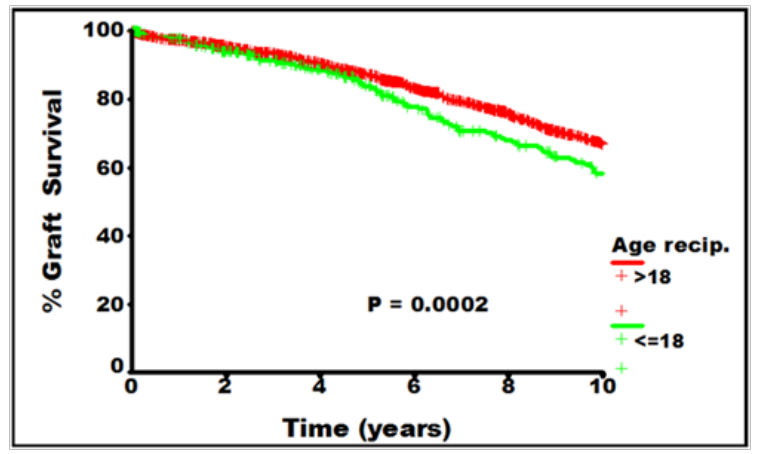

Figure 2 Graft survival.

The actuarial graft survival were $83.9+2.28,58.34+3.53$ pediatrics and $87.24+0.84,66.78+1.38$ for adults respectively, $p=0.0002$.

Table 3 Univariate analysis of risk factors of graft survival

\begin{tabular}{|c|c|c|c|c|}
\hline & \multicolumn{2}{|c|}{ Pediatric group (No. 338) } & \multicolumn{2}{|c|}{ Adults group (No. 1902) } \\
\hline & 10 years survival & $P$ value & 10 years survival & $P$ value \\
\hline $\begin{array}{l}\text { Recipient age } \\
(<12 / \geq 12)\end{array}$ & $78.4 / 71.2$ & 0.162 & ---------- & ------ \\
\hline $\begin{array}{l}\text { Donor age } \\
(<40 / \geq 40)\end{array}$ & $77.5 / 66.4$ & 0.19 & $83.1 / 70.2$ & $<0.001$ \\
\hline $\begin{array}{l}\text { Recipient sex } \\
\text { (Male/Female) }\end{array}$ & $68.7 / 83.5$ & 0.352 & $79.7 / 79.9$ & 0.897 \\
\hline Donor Male/Recipient Male & 70.3 & & 81.2 & \\
\hline Recipient female & 81.3 & & 84.3 & \\
\hline $\begin{array}{l}\text { Donor female/Recipient Male } \\
\text { Recipient female }\end{array}$ & $\begin{array}{l}63.2 \\
81.1\end{array}$ & 0.254 & $\begin{array}{l}77.9 \\
73.3\end{array}$ & 0.4 \\
\hline \multicolumn{5}{|l|}{ Original kidney disease } \\
\hline GN & 64.6 & & 76.7 & \\
\hline Ch. Pyeloneph. & 76.5 & & 82.3 & \\
\hline Hereditary GN & 70.7 & & 80.8 & \\
\hline End stage & 73.9 & 0.747 & 79 & 0.096 \\
\hline Prior blood transfusion (No/yes) & $73.7 / 72.4$ & 0.436 & $77.3 / 81.8$ & 0.503 \\
\hline \multicolumn{5}{|l|}{ Pre-emptive Tx } \\
\hline Yes & 85.3 & & 70.7 & \\
\hline Dialysis & 73.4 & 0.726 & 80 & 0.447 \\
\hline $\begin{array}{l}\text { Donor source } \\
\text { Related/unrelated }\end{array}$ & $73.2 / 74$ & 0.897 & $80.3 / 76.7$ & 0.509 \\
\hline \multicolumn{5}{|l|}{ Primary IS } \\
\hline Aza based & 58.6 & & 85.5 & \\
\hline Calcineurine based & 73.4 & & 78.6 & \\
\hline Steroid free & 94.1 & 0.017 & 81.3 & 0.064 \\
\hline $\begin{array}{l}\text { Time to diuresis } \\
\text { Immediate/delayed }\end{array}$ & $74 / 67.1$ & 0.320 & 79.8/79.I & 0.745 \\
\hline $\begin{array}{l}\text { ATN } \\
\text { (No/Yes) }\end{array}$ & $74.7 / 63$ & 0.164 & $79.8 / 78.4$ & 0.854 \\
\hline $\begin{array}{l}\text { Acute Rejection } \\
\text { (No/Yes) }\end{array}$ & $80.3 / 66$ & 0.023 & $83.5 / 70.8$ & $<0.001$ \\
\hline $\begin{array}{l}\text { Post transplant hypertension } \\
\text { (No/Yes) }\end{array}$ & $76.9 / 71.9$ & 0.374 & $85 / 77.4$ & $<0.001$ \\
\hline $\begin{array}{l}\text { Post transplant DM } \\
\text { (No/Yes) }\end{array}$ & $74 / 73.3$ & 0.78 & $79.8 / 78.8$ & 0.726 \\
\hline
\end{tabular}


Table 4 Multivariate analysis of risk factors of graft survival

\begin{tabular}{|c|c|c|c|c|}
\hline & \multicolumn{2}{|c|}{$\begin{array}{l}\text { Pediatric group (No. } \\
\text { 338) }\end{array}$} & \multicolumn{2}{|c|}{ Adults group (No. 1902) } \\
\hline & $\operatorname{Exp}(B)$ & P value & $\operatorname{Exp}(B)$ & $\begin{array}{l}\mathbf{P} \\
\text { value }\end{array}$ \\
\hline $\begin{array}{l}\text { Donor age } \\
<40 \\
>40\end{array}$ & $\begin{array}{l}\mathrm{I} .34(0.82- \\
2.20)\end{array}$ & 0.241 & $1.6 \mathrm{I}(1.28-2.03)$ & $<0.001$ \\
\hline $\begin{array}{l}\text { Primary IS } \\
\text { Aza based }\end{array}$ & $0.65(0.31-$ & & & \\
\hline $\begin{array}{l}\text { Calcineurine } \\
\text { based } \\
\text { Steroid free } \\
\text { based }\end{array}$ & $\begin{array}{l}\text { I.36) } \\
2.22(0.03- \\
1.84)\end{array}$ & $\begin{array}{l}0.249 \\
0.163\end{array}$ & $\begin{array}{l}\text { I.2I (0.90-I.63) } \\
\text { I.7I (I.08-2.7I) }\end{array}$ & $\begin{array}{l}0.206 \\
0.023\end{array}$ \\
\hline $\begin{array}{l}\text { Acute } \\
\text { rejection } \\
\text { No } \\
\text { Yes }\end{array}$ & $\begin{array}{l}1.72(1.06- \\
2.81)\end{array}$ & 0.03 & $2.0 I(I .6 I-2.5 I)$ & $<0.001$ \\
\hline $\begin{array}{l}\text { Post } \\
\text { transplant } \\
\text { HTN } \\
\text { No } \\
\text { Yes }\end{array}$ & $\begin{array}{l}\mathrm{I} .05(0.62- \\
\mathrm{I} .80)\end{array}$ & 0.853 & I.44 (I.II-I.87) & 0.007 \\
\hline
\end{tabular}

\section{Discussion}

Transplantation is the ideal treatment for pediatrics and young adults. Higher academic qualifications, normal marital life and job recruitments were associated with transplantation compared to regular haemodialysis. $^{2}$

In our results long term graft outcome was to be superior in adults compared to pediatrics as was reported by other groups. ${ }^{4}$ The actuarial graft survival at 5 and 10years were $87.24+0.84,66.78+1.38$ for adults and $83.9+2.28,58.34+3.53$ for pediatrics $(p<0.001)$. Numerous factors share in this long term inferiority in graft survival among pediatrics, the most important is poor compliance and recurrence of original kidney disease. ${ }^{3,5}$

Donor age was between 30-50years in pediatrics as the majority of donors were parents while in adults were younger as majority was either siblings or spouses. Pediatrics was encouraged for preemptive transplantation to avoid dialysis complications and rapid restoration of normal social life. While pre-emptive transplantation carries many advantages, it was reported that it may be associated with higher incidence of graft thrombosis. In our series we noticed higher incidence of graft thrombosis in pre-emptive group. ${ }^{6}$

We report better graft outcome in our series compared to other reports as all transplantation were done from living donor source. Deceased transplantation is not feasible yet in Egypt. It was believed that religion and cultural factors were behind the difficulties of starting the Deceased program in Egypt. After the success of deceased program in Islamic countries like Iran and Saudi Arabia. Egypt has launched new regulation and national law to regulate transplantation including the initiation of a national deceased program.

Initially, steroid avoidance was adopted for pediatrics in favor to avoid steroid related stunted growth, currently steroid avoidance is the standard immunosuppression protocol for both pediatrics and adults. In our series pediatrics tolerated well steroids avoidance with no impact on long term graft survival, our results in parallel with what have been published from other reports. ${ }^{7}$ No significant impact of immunosuppression was noted on long term graft survival in pediatrics. In adults steroid avoidance carried 1.7 independent risks on long term graft survival which can be explained by higher incidence of rejection compared to steroid based group; as well it was noticed high levels of tacrolimus after withdrawal of steroids with higher incidence of nephrotoxicity. ${ }^{8}$ The prevalence of post transplant hypertension in pediatric group was $50.6 \%$ and comparable to previously reported from other studies. ${ }^{9}$

Acute rejection was an independent risk factor of graft failure. One acute rejection increases the risk of long term graft failure 1.7times in pediatrics. While 2.01times the risk of lower graft survival following acute rejection in adults compared to those did not suffer acute rejection. As well donor age and post-transplant hypertension were independent risk factors in adults but have no impact in pediatric recipients.

\section{Conclusion}

In conclusion in spite of improved long term results more efforts must be directed toward management of risk factors that hinder further achievements.

\section{Acknowledgements}

None.

\section{Conflict of interest}

The author declares no conflict of interest.

\section{References}

1. Mir S, Erdogan H, Serdaroglu E, et al. Pediatric renal transplantation: single center experience. Pediatr Transplant. 2005;9(1):56-61.

2. Rocha S, Fonseca I, Silva N, et al. Impact of pediatric kidney transplantation on long-term professional and social outcomes. Transplant Proc. 2011;43(1):120-124.

3. Briganti E, Russ G, McNeil JJ, et al. Risk of renal allograft loss from recurrent glomerulonephritis. N Engl J Med. 2002;347:103-109.

4. Navarro TM, Espinosa RL. Children as receptors of living donors. Nefrologia. 2010;30(2):85-93.

5. Choy BY, Chan TM, Lai KN. Recurrent glomerulonephritis after kidney transplantation. American Journal of Transplantation. 2006;6(11):25352542 .

6. Mahmoud A, Said MH, Dawahra M, et al. Outcome of preemptive renal transplantation and pretransplantation dialysis in children. Pediatr Nephrol. 1997;11(5):537-541.

7. Delucchi A, Valenzuela M, Lillo AM, et al. Early steroid withdrawal in pediatric renal transplant: five years of follow-up. Pediatr Nephrol. 2011;26(12):2235-2244.

8. Gheith OA, Nematalla AH, Bakr MA, et al. Steroid avoidance reduce the cost of morbidities after live-donor renal allotransplants: a prospective, randomized, controlled study. Exp Clin Transplant. 2011;9(2):121-127.

9. Hernandez-Infante E, Garcia-Martinez C, Berltran-de-la-Luz S, et al. Prevalence of post transplant hypertension in pediatric kidney transplant recipients: effects on long term allograft survival. Rev Invest Clin. 2010;62(5):398-405. 